\title{
THE MELKITES AND THE MUSLIMS: THE QUR'ĀN, CHRISTOLOGY, AND ARAB ORTHODOXY
}

\author{
MELQUITAS Y MUSULMANES: EL CORÁN, \\ CRISTOLOGÍA Y ORTODOXIA ÁRABE
}

SiDNEY H. GRIFFITH

The Catholic University of America, Washington D.C., USA

The earliest Chalcedonian writers to take notice of the religious ideas of the invading Arabs at the time of the Islamic conquest of the Middle East already highlighted what they viewed as wrong or confused notions about Christ on the part of the invaders. Then in the mid-eighth century, Arabic-speaking Chalcedonians in Syria/Palestine, whose adversaries would soon be calling them 'Melkites', were quoting the Qur'ān with a view to exploiting the probative potential of its language for apologetic purposes, especially in Christology. This article traces the continued focus on Christology and the Qur'ān in the development of Chalcedonian theology in Arabic in the works of the major writers in the early 'Melkite' tradition, suggesting that the 'Melkite' community's engagement with the religious challenge of Islam over time issued in the emergence of a recognizeable Arab Christian Orthodoxy, which the term 'Melkite' came to designate.

Key words: Melkites; Chalcedonians; Arab Christians; Arabicization; Christology.
Durante la expansión del Islam por Oriente Medio, los primeros autores calcedonianos que tuvieron conocimiento de las ideas religiosas que los invasores árabes traían, pusieron de relieve ciertas nociones que ellos entendían como confusas o negativas sobre Cristo. A mediados del siglo VIII, los araboparlantes calcedonianos de Siria-Palestina (que pronto serían denominados «Melquitas» por sus adversarios), comenzaron a citar el Corán con la intención de explotar el potencial probatorio de la lengua para propósitos apologéticos, especialmente en Cristología. Este artículo rastrea ese enfoque en la Cristología y el Corán, que se mantiene de forma continuada en el desarrollo de la teología calcedoniana en lengua árabe, en los trabajos de los más importantes autores de la tradición melquita temprana. Este análisis nos hace pensar que ese «combate» de la comunidad melquita como reacción al desafío religioso del Islam, con el paso del tiempo, hace necesaria una ortodoxia árabe-cristiana reconocible que vendría a ser designada con el término Melquita.

Palabras clave: Melquitas; calcedonianos; cristianos árabes; arabización; Cristología.

When in the second third of the seventh century CE Arab Muslims invaded and occupied Syria/Palestine, including the territories of the patriarchates of Antioch and Jerusalem, local Christians whose ec- 
clesial community would in the future come to be called 'Melkite' in the Arabic-speaking world were among the first to take notice of them. At the time of the invasion, they were for the most part Greek and Syriac-speaking confessors of the Chalcedonian faith, who throughout the seventh century were engaged in controversy with the theologians of Constantinople over the imperially supported doctrines of 'Monenergism' and 'Monotheletism'. The monasteries of Jerusalem and the Judean desert, and to a certain extent the ecclesiastical establishment in Edessa in Syria, were their intellectual centers. Their doctrinal heritage would in the first half of the eighth century find its definitive exposition in the Greek works of St. John of Damascus (c.655-c.750). By the ninth century, their theologians had already adopted Arabic and their Christian and Muslim confessional adversaries in the Arabic-speaking World of Islam were referring to them as 'Melkites' because of their acceptance of the doctrinal decisions of the imperially sponsored, sixth ecumenical council in Byzantium, Constantinople III (681 CE), along with its five equally imperially sponsored predecessors. In due course the 'Melkites' assumed a distinctive, 'Arab Orthodox' Christian identity and became a thriving ecclesial community among the churches in the Oriental Patriarchates. After the year 1724 however, the epithet 'Melkite' has come to be used in the west in a narrower sense in common parlance to designate the largely Arabic-speaking, Melkite, Greek Catholic Church, an ecclesial community that for a variety of reasons in the eighteenth century emerged from the congregations of the Orthodox patriarchates of Antioch, Alexandria and Jerusalem and entered into union with Rome. ${ }^{1}$

From their first encounters with the Muslims, the Chalcedonian Christians who would become the 'Melkites' perceived the Christological challenge inherent in the religious beliefs of the Arabs who occupied the Levant in the first half of the seventh century. By the middle of the eighth century these same Christians began the process of translating their confessional heritage into Arabic and by the middle of the ninth century others were normally calling them 'Melkites'. Christology continued to dominate 'Melkite' theology well into the thirteenth century and even in their controversies with their

${ }^{1}$ Haddad, Syrian Christians in Muslim Society; Haddad, "Conversion of Eastern Orthodox Christians".

Al-Qantara XXXIII 2, 2012, pp. 413-443 ISSN 0211-3589 doi:10.3989/alqantara.2012.004 
Christian confessional adversaries in the Islamic world, 'Melkites' were ever aware of the challenge of the Arabic Qur'ān and the diction of the Islamic scripture echoed more often in their writings than it did in the works of all the other Arabic-speaking Christians in the caliphate.

\section{The Conquest and the Challenge}

The Christian writers who first took notice of the Arab invasions in the 630's registered their alarm at the approach of the invaders, whom they as often as not called 'Saracens', 'Hagarenes' or 'Ishmaelites' ${ }^{2}$ and from the beginning they seem to have been aware of the Arabs' religious ideas, particularly about Christ, as we shall see. Of particular interest at the outset are texts which refer to the Arab occupation of Jerusalem and the establishment of a Muslim place of prayer on the Temple Mount. From the very beginning of the confrontation between the Muslims and the Christians outside of Arabia, Jerusalem quickly became the symbolic location of both their doctrinal and their political rivalries. It began already at the conquest, in the time of Patriarch Sophronios of Jerusalem (d.c.639 CE) and Caliph 'Umar I (r.634-644), both of whom quickly became the literary figures of record in both the Christian and the Muslim narratives of the surrender of Jerusalem.

We find Patriarch Sophronios' remarks about those whom he took to be marauding Arabs in his sermons on holy days like Christmas and the Epiphany in the years between 634 and 637. Already in his synodical letter on the occasion of taking possession of his see, the patriarch had spoken of the fear of the Saracens, "who, on account of our sins, have now risen up against us unexpectedly and ravage all with cruel and feral design, with impious and godless audacity." ${ }^{3}$ In his sermon on the Epiphany, probably in the year 636, Sophronios gave a description of events that is more easily recognizable as a report of Arab campaigns in the Jerusalem area in service of the Is-

2 These derogatory terms had long been used by Christian writers to refer to the Bedouin Arabs of the desert; in Islamic times they were transferred to the Muslims. See their regular use in the many texts cited by Hoyland, Seeing Islam As Others Saw It and Hoyland, Arabia and the Arabs.

${ }^{3}$ Quoted from Hoyland, Seeing Islam As Others Saw It, p. 69.

Al-Qanțara XXXIII 2, 2012, pp. 413-443 ISSN 0211-3589 doi:10.3989/alqantara.2012.004 
lamic conquest. Once again he spoke of the sins of the Christians as having brought on the depredations. He said,

\begin{abstract}
That is why the vengeful and God-hating Saracens, the abomination of desolation clearly foretold to us by the prophets, overrun the places which are not allowed to them, plunder cities, devastate fields, burn down villages, set on fire the holy churches, overturn the sacred monasteries, oppose the Byzantine armies arrayed against them, and in fighting raise up the trophies [of war] and add victory to victory. Moreover, they are raised up more and more against us and increase their blasphemy of Christ and the church, and utter wicked blasphemies against God. ${ }^{4}$
\end{abstract}

One recognizes especially in the final sentence the patriarch's reaction to what he obviously took to be the blasphemous character of the invading Arabs' religious ideas. The Arabs finally took possession of Jerusalem in the year 637 and in due course they established a mosque there, most probably on the Temple Mount. ${ }^{5}$ Subsequently, Jerusalem became both the site and the symbol of the confrontation between Christianity and Islam, a symbolism that would be displayed in the very architecture of the Islamic appropriation of the Holy City in the late seventh century. Meanwhile, Damascus had fallen to the Arabs in the year 635, Antioch, like Jerusalem in 637, and then Edessa in Syria in 640, Alexandria in Egypt in 642, and SeleuciaCtisiphon, the capital of Sassanid Persia in 645. So within just a dozen years after the death of Muhammad, and by the midpoint of the seventh century, three of the five patriarchates of the Christians, including the Persian seat of the catholicos of the 'Church of the East', had come under the permanent rule of the Arabian prophet's enthusiastic followers.

It was in Jerusalem, the 'Mother of the Churches', as the local Chalcedonian champion of the sixth century, Cyril of Scythopolis (b.c.525), had called the city, ${ }^{6}$ that during the last decade of the seventh century, the caliph 'Abd al-Malik (685-707), beginning in the year 692, patronized the construction of the Dome of the Rock, a monumental statement to Jews and Christians alike of Islam's cultural and religious hegemony. In the cityscape of Jerusalem in the late seventh century, the Dome of the Rock stood seemingly by de-

${ }^{4}$ Quoted from Hoyland, Seeing Islam As Others Saw It, p. 73.

5 See Busse, "Zur Geschichte" and Busse, "Die "Umar-Moschee".

${ }^{6}$ See Wilken, The Land Called Holy, p. 171. 
sign over against the dominance of the skyline hitherto enjoyed by the Church of the Anastasis/the Holy Sepulchre and other Christian structures in the city. ${ }^{7}$ What is more, the beautiful Kufic inscription in gold leaf that goes around the base of the dome, on both its inner and outer faces, using passages from the Qur'ān, over and over again proclaims:

There is no god but God alone. ... He did not beget and was not begotten. ... Muhammad is the messenger of God. Such too was Jesus, son of Mary. ... Praise be to God who has not taken a son. ... Religion with God is Islam. ... Those who had been given the scripture differed only after knowledge came to them, out of rivalry with one another. ${ }^{8}$

The import of these repeated Qur'ānic phrases is crystal clear: Islam has supplanted Christianity even in Jerusalem, and even on the Temple Mount where previously Christians had seen the signs of their own succession to the Jews in the ruins of the Second Temple. ${ }^{9}$ Symbolically and chronologically, if not directly engaging the Christians, the construction of the Dome of the Rock, along with the declarative intent of the inscriptions, marked the beginning of the era when Christians living in the caliphate seriously undertook the task of responding to the monumentally proclaimed Islamic challenge.

\section{Christology, the Muslims, and the Proto-'Melkites'}

Already in his Epiphany sermon, Patriarch Sophronios had spoken of the invading Arabs' "blasphemy of Christ," and their "blasphemies against God." And in "Abd al-Malik's inscription at the base of the Dome of the Rock, the Islamic emphasis on Jesus' humanity and the denial of his divinity is clearly proclaimed. So too does the inscription echo the Qur'ān's allusions to the Scripture People's (ahl al-kitāb) differences among themselves over doctrinal matters; they "differed only after knowledge came to them, out of rivalry with one another." (III $\bar{A} l$ 'Imrān 19) It is as if the inscription, with its Qur'ān quotations, was intended directly to allude to the Christological controversies then

${ }^{7}$ See Grabar, The Shape of the Holy and Grabar, The Dome of the Rock.

${ }^{8}$ Kessler, "Abd al-Malik's Inscription"; Grabar, The Shape of the Holy, pp. 56-71 and pp. 184-185.

9 See Busse, "Monotheismus und islamische Christologie". 
current among Christians and especially in Jerusalem. In fact the case could be made that the principal difference between Muslims and Christians, expressed already in the Qur'ān, was precisely what truthfully could be said about Jesus of Nazareth, the confession of whose status as 'son of God' led Christians, according to the Qur'ān, to speak of God in terms of 'three'. (cf. IV al-Nisà' 171) And this centrality of Christology and the theological consequences it entailed was certainly the principal religious concern of the earliest writers among the proto-'Melkites' who took notice of the challenge of Islam.

In the 690's, a monk in the monastic communities of Sinai, Anastasios of Sinai (d.c.700), who was a staunch supporter of the teachings of the 'six councils' of Byzantine Orthodoxy, wrote a book called in Greek Hodegos (The Guide). His purpose was to support the teachings of the councils against those whom he regarded as 'Monophysites', and particularly against the teachings to be found in the works of Patriarch Severus of Antioch (c.465-538). In the course of his work he refers a number of times to what he calls the "false notions of the Arabs," notions that the reader easily recognizes as Islamic ideas. For Anastasios makes no explicit reference to Muhammad, the Qur'ān or to Islam. ${ }^{10}$ But in the preface to the Hodegos, Anastasios sets forth his reasons for writing the book. Having listed ten reasons stemming from intra-Christian concerns, he also offers the following one:

\footnotetext{
Because, prior to any discussion at all, we must condemn however many false notions about us the opponent has, as when we set out to converse with Arabs we have first to condemn anyone who says, "Two gods," or anyone who says, "God has carnally begotten a son," or anyone who makes prostration as to God, to any creature whatever, in heaven or on earth. Likewise, in regard to the rest of the heresies, it is necessary first to condemn however many false opinions about the faith they have. For, giving heed to these things, they accept the rest the more eagerly. ${ }^{11}$
}

The first thing to notice in this passage is that religious controversy with Arabs is put forward as a familiar instance of the procedure Anastasios is proposing to follow in the Hodegos. Further it is clear that what should first be rebutted, in Anastasios' view, are the false notions the opponent already harbors. He gives three examples of such notions, from what his reader is expected easily to recognize

${ }^{10}$ See Griffith, "Anastasios of Sinai".

${ }^{11}$ Uthemann, Viae Dux, p. 9. 
as false Arab notions about what orthodox Christians believe. They can all be found in the Qur'ān, in the very terms in which Anastasios mentions them.

First of all, the Qur'ān contains a clear rejection of the polytheism of the pagan Arabs, and one finds there the explicit injunction, "God said, 'Do not accept two gods. There is but a single God. So fear me." (XVI al-Nahl 51) This same language appears again to reject what the Qur'ān perceives to be the erroneous core of Christian preaching about Jesus, son of Mary, in the description of a scene in which Jesus stands in judgment before God: "God said, 'O Jesus, son of Mary, did you tell people, 'Take me and my mother for two gods instead of God'?" (V al-Má'idah 116) Surely the standard Christian proclamation that Jesus is God, the son of God, and Mary his mother, is the mother of God, would have been sufficient to elicit the Qur'ān's adverse judgment. The Muslim Arabs invading Palestine and Sinai would have thought, on the basis of the Qur'ān's statement, that Christians do teach that Jesus and his mother were two gods. Accordingly, Anastasios reminds his reader that this is a false notion about Christians that one must condemn before engaging in controversy with Arabs.

The false Arab notion that what Christians believe involves God in the carnal generation of a son also has its roots in the Qur'ān. A constant feature of the Islamic scripture's critique of Christian teaching is the phrase, "They say God has taken a son; praised be He. No, whatever is in the heavens or on the earth is His, all are subservient to Him." (II al-Baqarah 116) Anastasios' very wording of this false Arab notion, as he would have it, once again ties the rejection of a Christian doctrine in with the Qur'ān's earlier rejection of pagan ideas, as in VI al-An'ām 101, where the assumption that God has offspring is explicitly associated with the unacceptable notion that such a proposal would involve God with a female consort: "The Creator of heaven and earth - how does He have offspring? He did not have a female consort. He created everything." Clearly then, in the Qur'ān's view, to say that God has a son, or that Jesus Christ is God's son, would involve God in a twofold impossibility: it posits Mary as God's consort; and Jesus and Mary as two gods instead of God. These are precisely the false notions about what Christians teach that Anastasios says one must clearly anathematize before arguing with Arabs. 
In the Qur'ān's view, to make a prostration to Jesus, son of Mary, as to God, would of necessity involve one in the worship of creatures. Accordingly, Anastasios notes that before arguing with Arabs one must anathematize whoever worships any creature in heaven or on earth. (cf. Exodus XX:4-6; Deuteronomy V:8-10) He assumes it is a false notion of the Arabs that Christians are guilty of such misguided worship. One supposes that the reference is to the Christian practice of bowing down before the cross and the images of Christ and the saints. The Qur'ān says, "Do not prostrate yourselves to the sun or to the moon, but prostrate yourselves to God who created them, if it is He you truly worship." (XLI Fușșilat 37).

From this and other passages in the Hodegos, it is clear that Anastasios in the Sinai in the late seventh century was aware of the Qur'ānic terms of Muslim religious teaching, and that he was accustomed to having conversations with Muslim Arabs, presumably in Arabic, about ways in which he thinks they are mistaken in what they believe about Christian teaching about Jesus. Furthermore, Anastasios obviously thought that it was appropriate to consider the Arabs' teaching about Jesus to be a kind of Christian heresy. Having spoken of the false notions of the Arabs, he went on to say, "Likewise, in regard to the rest of the heresies, it is necessary first to condemn however many false opinions about the faith they have." ${ }^{12}$ And it is clear that Anastasios thought that the Arabs' false opinions were Arian in theological significance; in a number of places in his works he simply refers to the Arabs as Arians. ${ }^{13}$

Anastasios' intimation that he thinks of the false notions of the Arabs as being among the heresies of his time immediately puts one in mind of what St. John of Damascus (d.c. 749/753) wrote about the 'religion of the Ishmaelites' in the De Haeresibus section of his magnum opus, the compendium of Christian teaching that he called The Fount of Knowledge. In his presentation of Islam in Chapter 100 of the De Haeresibus, he speaks of "the now ruling, misleading religion (thrēskeia) of the Ishmaelites," presaging the coming of the Antichrist. He says that it was introduced by the false prophet Muhammad (Mamed), who founded his own 'heresy' (hairesin) having taken cognizance of the Old Testament and the New Testament and having

${ }^{12}$ Uthemann, Viae Dux, p. 9.

${ }_{13}$ Munitiz, Anastasios of Sinai, pp. 183-185. 
frequented the company of a seemingly Arian monk and being in receipt of a 'scripture (graphèn) revealed by God that came down to him from heaven. He put together some laughable teachings in a book of his own and thus he handed over to them this particular manner of 'worship' (to sebas). ${ }^{14}$

What one wants to highlight here is the language John used to characterize Islam as he knew it. He calls it a 'religion', a 'heresy', and 'a way of worship'. Two of these terms ('religion' and 'way of worship) would seem to put Islam outside the circle of the religious insiders with whom he is largely concerned in most of his work, i.e., those whom he thinks of as Orthodox, the 'Chalcedonians' who also accept the teachings of the sixth ecumenical council, Constantinople III, along with their 'in-house' adversaries such as the contemporary 'Monotheletes', the 'Jacobites', and the 'Nestorians'. As for his designation of Islam as a 'heresy' founded by Muhammad, this is a term that was generally used in Patristic texts written in Greek, in contradistinction to the term 'schism', to mean, from a given author's or church's point of view, a wrong understanding of the nature of Christ. ${ }^{15}$ This meaning in the present context is reaffirmed by John's mention of a "seemingly Arian monk," with whom Muhammad is said to have been in contact. Accordingly, by explicitly using the term 'heresy' here, John of Damascus is signaling his view that what is principally wrong with Islam from a theological point of view is its heretical understanding of Jesus Christ.

Furthermore, and in connection with the related issue of the Christian practice of the veneration of the cross and of the icons of Jesus, Mary, and the saints, one recalls that Anastasios of Sinai also said in the Hodegos that before conversing with the Arabs, one must anathematize "anyone who makes prostration as to God, to any creature whatever, in heaven or on earth." 16 This advice may be taken as evidence that already at the turn of the eighth century religious images had become a point of controversy between Christians and Muslim Arabs. This fact in turn reminds one that not only was John of Damascus' Fount of Knowledge composed at least in part in response to the theological and religious challenge of Islam more

${ }^{14}$ See Le Coz, Jean Damascène, pp. 210-212.

15 See Lampe, A Patristic Greek Lexicon, p. 51.

${ }^{16}$ Uthemann, Viae Dux, p. 9. 
broadly, ${ }^{17}$ but so too were his three famous orations, Against the Iconoclasts, composed at least in part against challenges coming from Muslims; in these orations the Chalcedonian Christology he defended was also clearly implicated. ${ }^{18}$ Here is not the place to discuss this matter in any detail; it will come up again as an important topic in the 'Melkite' theological reaction to the challenge of Islam in the Arabic treatises of later writers.

Patriarch Sophronios of Jerusalem, Anastasios of Sinai, and St. John of Damascus were three of the proto-Melkites in Syria/Palestine writing in Greek in the seventh and early eighth centuries in whose works we find the earliest references to the Islamic conquest and to the challenging religious ideas of the Muslim Arabs. They, along with earlier Palestinian Greek writers, such as Maximus the Confessor (c580-662), the now unknown author of the pseudo-Athanasian Quaestiones ad Antiochum Ducem, and the local compilers of the popular, Chalcedonian reference books, the Doctrina Patrum and the Sacra Parallela, were the proto-'Melkites' who articulated the 'Orthodoxy of the Six Councils' that along with the later adoption of the teaching of the seventh ecumenical council, Nicea II in 787, became the archival backbone of Byzantine Orthodoxy as it was definitively presented in the ninth century Synodicon of Orthodoxy. ${ }^{19}$ The works of these writers and compilers, and especially the works of St. John of Damascus, with their dominant concern for Christology, were to be constantly in the background for the Arabic-speaking, 'Melkite' writers who from the late eighth century until well into the thirteenth century struggled to make the Orthodox Christian teaching of the ecumenical councils intelligible in Arabic. This intellectual project in fact constituted the principal reaction of the 'Melkites' to the Arab conquest of the seventh century.

${ }^{17}$ See this point argued in Griffith, "Giovanni di Damasco" and Griffith, "John of Damascus and the Church".

${ }^{18}$ See Louth, St John Damascene.

${ }^{19}$ See these matters discussed in more detail in Griffith, "John of Damascus and the Church".

Al-Qanțara XXXIII 2, 2012, pp. 413-443 ISSN 0211-3589 doi:10.3989/alqantara.2012.004 


\section{The 'Melkites' in the 'World of Islam'}

It was already Islamic times when their Syriac and Arabic-speaking, 'Jacobite' and 'Nestorian' adversaries first used the contentious epithet 'Melkites', in the sense of 'royalists' or 'emperor's men', polemically to characterize their Christological and ecclesial adversaries in the east who unlike them accepted the orthodoxy of the first six Ecumenical Councils, and who championed the theology of Maximus the Confessor, Anastasius of Sinai, and John of Damascus. Properly speaking therefore the 'Melkites' constitute a distinctive community of Arabic-speaking Christians, living in the 'World of Islam', in the patriarchal sees of Alexandria, Antioch, and Jerusalem, and composing an Arab Orthodox Church, whose Christology is Chalcedonian, and who from the late seventh century on have lived in communion with the Greek Orthodox see of Constantinople. ${ }^{20}$ The 'Melkites' were the first Christian community to adopt Arabic. And from the beginning their principal reaction to the Arab conquest was the undertaking to present Orthodox Christian doctrine and practice in good, clear Arabic, particularly in the explication and defense of the doctrines of the Incarnation and the Holy Trinity, in the theological and philosophical idiom of the Arabic-speaking, Muslim intellectuals from the eighth to the thirteenth centuries.

Already in the eighth century, 'Melkite' scholars in the monasteries of Jerusalem and the Judaean Desert were producing Arabic translations of the Christian scriptures, saints' lives, and patristic texts. ${ }^{21}$ By the second third of the century one of their number, whose name is now lost to us, wrote the earliest known, original Christian composition in Arabic, called by its modern editor, "On the Triune Nature of God." ${ }^{22}$ In it he defends the credibility of the doctrines of the Trinity and the Incarnation, buttressing his reasoning with quotations from the Old Testament, the New Testament, and even from the Qur'ān. And in this respect, as we shall see below, he set the agenda for subsequent 'Melkite' writers in Arabic, who, like the proto-'Melkites', were quick

${ }^{20}$ See Griffith, "'Melkites', 'Jacobites"”; Griffith, "Theology and the Arab Christian"; Griffith, "The Church of Jerusalem". See also in this connection, Griffith, "The Life of Theodore of Edessa".

${ }^{21}$ See Griffith, "The Monks of Palestine" and Griffith, "From Aramaic to Arabic".

22 Dunlop Gibson, An Arabic Version; Gallo, Palestinese anonimo. See Samir, "The Earliest Arab Apology". 
to perceive that the basic Islamic challenge for Christian doctrine lay in what the Qur'ān says about the Christian confession that Jesus of Nazareth is the Son of God, the creedal affirmation that in turn entails the doctrine of the Trinity, as the Qur'ān clearly perceives. The author of the anonymous treatise "On the Triune Nature of God" became the first in a long line of Arabic-speaking, Christian apologists to turn their attention to the Qur'ân's most striking verse in this connection, the verse that Christian writers most often quoted or alluded to of all Qur'ānic verses. The Qur'ān says:
O People of the Book, do not go beyond the bounds in your religion, nor say about God anything but the truth. The Messiah, Jesus, son of Mary, is only God's messenger and His word, which He imparted to Mary, and he is a spirit from Him. So believe in God and in His messengers, and do not say 'three'. Stop it; it is better for you. God is truly one God. How - glory be to Him - could He have a son? To Him belongs what is in the Heavens and on earth. God suffices as a patron. (IV al-Nisā' 171).

On the face of it, this verse speaks of God and of Jesus as God's word and as a spirit from Him. The anonymous author of the treatise "On the Triune Nature of God" was quick to notice that notwithstanding the polemical intent of the verse, here the Qur'ān actually mentions the Christian 'three', what the Christians call the three persons or hypostases of the Trinity, God, God's Word, and God's Spirit. Of course, as the Qur'ân puts it, it is Jesus who is God's word and a spirit from Him, a formulation that simultaneously retrieves, critiques, and, from the Qur'ān's point of view, corrects Christian confessional language. Nevertheless, the Christian apologist cites the language of the verse as the Qur'ān's testimony to God, to God's Word, and to God's Spirit. Subsequent 'Melkite' writers seldom failed to quote or to allude to this Qur'ānic verse for the same purpose, thereby highlighting their perception that the principal Islamic critique of Christianity lay in what the Qur'ān's says about Jesus, the Messiah, the son of Mary.

From the ninth century to the thirteenth century, 'Melkite' scholars strove to give full expression to their Christian faith in Arabic, with all its confessional nuances. ${ }^{23}$ In the process they partook fully

${ }^{23}$ The only 'Melkite'-specific accounts of this literature are to be found in Graf, Geschichte der christlichen arabischen Literatur; Nasrallah, Histoire de movement littéraire. In other works, the 'Melkite' writers are discussed chronologically along with 
in the intellectual life of the developing Islamic culture, thereby contributing in no small part, along with the scholars of the other Christian denominations in the World of Islam, to the evolution in Abbasid times of the classical modes of intellectual life in the Arabic language. ${ }^{24}$ It was precisely this strong development of an intellectual life in Arabic, in dialogue with the currents of philosophical, religious, and political thought among the Muslims, that constituted the principal 'Melkite' reaction to the Arab conquest and the subsequent Islamic hegemony over the 'Oriental Patriarchates'. In Arabic, 'Melkite' religious thinkers from Theodore Abū Qurrah (c.755-c.830) to Paul of Antioch ( $f l$. c. 1220) wrote Christian theology "with-a-mindfor-Islam," to borrow a phrase from Kenneth Cragg. ${ }^{25}$ Like other Arab Christian writers of the period, they wrote primarily for the benefit of their own Arabophone confessional community, to clarify their creedal allegiances vis-à-vis other Christians, and to respond to the challenge the Qur'ān and the 'Call to Islam' posed for their coreligionists. ${ }^{26}$ The very fact that they wrote in Arabic and their works circulated in the Arabic-speaking 'World of Islam' itself constituted a solicitation to controversy with Muslims, a bid that Muslim writers even in the early period sometimes accepted. ${ }^{27}$ And it was within this context of a full intellectual acculturation into the modes of discourse of the commonwealth of Islam that there emerged among the 'Melkite' writers in particular the apologetic ploy of arguing in behalf of the veracity of the Christian religion and its doctrines by citing prooftexts drawn from the Qur'ān, and adjusting them to the requirements of a Christian interpretation.

writers from the other Arabic-speaking Christian communities, and sometimes along with Muslim writers as well. See, e.g., the still emerging work of Thomas et al., Christian-Muslim Relations. An anthology of 'Melkite' Arabic texts in English translation is about to appear: Noble and Treiger, The Orthodox Church in the Arab World.

${ }^{24}$ See in this connection Samir, "The Christian Communities" and Samir, "La rivoluzione cultural".

${ }^{25}$ Cragg, The Arab Christian, p. 291.

${ }^{26}$ For the broader context see Griffith, The Church in the Shadow.

${ }^{27}$ According to the Muslim bibliographer, Muhammad b. Ishāq b. al-Nadīm, in the instance of Theodore Abū Qurrah, the Mu'tazilī mutakallim Abù Mūsā 'Īsā b. Șubayh al-Murdār (d.c.840) is on record as having written a tract, Against Abū Qurrah, the Christian, which unfortunately is not known to have survived. See Dodge, The Fihrist of al-Nadìm, p. 394. 


\section{The 'Melkites' and the Qur'ān}

From the very beginning, as we have seen, the "false notions" 28 of the Arabs about Jesus Christ as reflected in passages from the Qur'ān had already come to the attention of the proto-'Melkite', Greek writers of Palestine in the seventh and eighth centuries. It is no surprise then to discover that the Arabic-speaking, 'Melkite' writers from the late eighth century onward turned their attention to the Islamic scripture for both polemical and apologetic purposes. They were not alone in this undertaking; other Arab Christian controversialists were parties to the effort both apologetically to claim Christian origins for the Qur'ān, along with Christian interpretations of its text, and polemically to demean it as a credible scripture. The reason for this attention to the Qur'ān is not hard to discern. As one Arab Christian writer put it to his alleged Muslim interlocutor, "You are committed to saying that for you the strongest argument is this scripture (kitāb), which you have in your possession." 29

Christian writers in the early eighth century were already in the habit of speaking to Muslims of "the Qur'ān, which Muhammad taught you," 30 thereby suggesting its human origins. John of Damascus put the point even more directly; he said that Muhammad "spread rumors that a scripture (graphēn) was brought down to him from heaven." ${ }^{31}$ John went on to say, "This Muhammad, as has been mentioned, composed many idle tales, onto each of which he prefixed a title," and he goes on to mention some of the names of the sürahs, not accurately, but recognizably: The Woman, God's Camel, the Table, the Heifer. ${ }^{32}$ And John held up some of the Qur'ān's stories for ridicule, as in the accounts of Abraham, Hagar, Ishmael, the Ka'bah, the recollection of the affair of Zayd's wife, along with the belittling reference to what he calls, "the book of God's camel." John was also the first to opine that given his religious ideas, Muhammad must have

${ }^{28}$ The expression of Anastasios of Sinai in his Hodegos; Uthemann, Viae Dux, p. 9.

29 Tien, Risālah 'Abd Allāh ibn Ismā'ìl, p. 126.

${ }^{30}$ The remark of the unnamed monk of Beth Hālè to a visiting Arab notable recorded in the still unpublished Syriac account of their conversation; quoted from Hoyland, Seeing Islam As Others Saw It, p. 471.

${ }^{31}$ Le Coz, Jean Damascène, p. 210.

${ }^{32}$ Le Coz, Jean Damascène, pp. 210-212. 
been in conversation with a "seemingly Arian monk." ${ }^{33}$ Doubtless this remark was meant to express a theological judgment regarding the Qur'ān's Christology, but John may well also have known the Islamic tradition according to which an errant, Christian monk had confirmed Muhammad's status as a prophet. ${ }^{34}$

In the ninth century, first in Syriac and then in an Arabic recension, now anonymous Christian writers, taking advantage of the currency of the Islamic tradition about the monk Bahịrā's recognition of Muhammad as God's messenger, composed a long legend according to which the supposedly heretical monk actually taught Muhammad monotheism and tutored him in the course of his mission to the Arabs, even providing him with the verses of the Qur'ān. ${ }^{35}$ In this telling at the hands of Christian apologists and polemicists the Qur'ān is claimed as an originally Christian book, albeit that in the end, according to the story, Jews altered and distorted the Arab prophet's teaching. On the one hand this Christian Bahīrā legend demeaned the Qur'ān, claiming a human origin for it, but on the other hand it also transformed it into a scripture in which Christian apologists could claim to find authentic Christian meanings.

A little later in the ninth century, and taking advantage of the currency of the Bahīrā legend among Christians living in the Islamic world, the now unknown Christian author or authors of the aforementioned al-Hāshimì/al-Kindī correspondence, at least one of whom just may have been a 'Melkite', ${ }^{36}$ sought to discount the Qur'ān as the Muslim interlocutor's "weightiest argument" by destroying its credibility as a scripture. The al-Kindī character polemically undermined the principal Muslim claims for the authority of the Qur'ân and impugned the idea that it could reasonably be held to be anything but a second rate and very fallible human composition. ${ }^{37}$ But given the fact that in spite of such polemical attacks on

${ }^{33}$ Le Coz, Jean Damascène, p. 210.

34 The biographical traditions regarding Muhammad that circulated among Muslims already in the eighth century refer in this connection to the monk Bahīrā. See Guillaume, The Life of Muhammad, pp. 79-81.

${ }^{35}$ See now the magisterial study by Roggema, The Legend of Sergius Bahīrāa. See also Roggema, "A Christian Reading of the Qur'ān".

36 See Bottini, "The Apology of al-Kindī".

${ }^{37}$ See Tien, Risālah 'Abd Allāh ibn Ismā' $\bar{l} l$, pp. 126-155. See too the remarks of Platti, "Des arabes chrétiens et le Coran". 
the part of its adversaries the Qur'ān remained the one authoritative scripture for Muslims, Christian apologists, and particularly 'Melkites', were not slow to recognize the probative potential of using quotations from the Qur'ān as proof-texts in tracts intended to bolster the faith of their fellow Christian readers as well as to suggest the verisimilitude of Christian doctrines to any Muslim reader who might come across their works.

As mentioned above, the use of quotations from the Qur'ān for their probative potential was a feature of the very earliest 'Melkite' text in Arabic, the treatise 'On the Triune Nature of God'. And this usage was not confined to the author's evocation of the Qur'ān's statement that Jesus, the Messiah, Mary's son, was God's word and a spirit from Him in IV al-Nisā' 171, as was mentioned above. As a matter of fact, the whole treatise is suffused with echoes of the Qur'ān, and not just in quotations and allusions to verses here and there but even in its diction and style. It will repay us to take a more extended look at this feature of the work.

In the poetical introduction to the treatise, by allusion and choice of words and phrases the author already echoed the diction and style of the Qur'ān. ${ }^{38}$ As Mark Swanson has rightly remarked, "The text simply is profoundly Qur'ānic." 39 One can see it even in English translation, as in this brief passage from the opening prayer:

We ask you, O God, by your mercy and your power, to put us among those who know your truth, follow your will, and avoid your wrath,

[who] praise your beautiful names, (Q VII:180)

and speak of your exalted similes. (cf. Q XXX:27)

You are the compassionate One, the merciful, the most compassionate;

You are seated on the throne, (Q VII:54)

You are higher than creatures;

You fill up all things. ${ }^{40}$

Shortly after this prayer, the author makes a statement that may well serve as an expression of his purpose in composing his work.

${ }^{38}$ See Samir, "The Earliest Arab Apology", pp. 69-70; Swanson, "Beyond Prooftexting", pp. 305-308.

${ }^{39}$ Swanson, "Beyond Prooftexting", p. 308.

40 Adapted from the text and translation in Samir, "The Earliest Arab Apology", pp. 67-68.

Al-Qanțara XXXIII 2, 2012, pp. 413-443 ISSN 0211-3589 doi:10.3989/alqantara.2012.004 
Again, the attentive reader can hear the Qur'ānic overtones clearly. The author says,

We praise you, O God, and we adore you and we glorify you in your creative
Word and your holy, life-giving Spirit, one God, and one Lord, and one Creator.
We do not separate God from his Word and his Spirit. God showed his power
and his light in the Law and the Prophets, and the Psalms and the Gospel, that
God and his Word and his Spirit are one God and one Lord. We will show this,
God willing, in those revealed scriptures, to anyone who wants insight, under-
stands things, recognizes the truth, and opens his breast to believe in God and
his scriptures. ${ }^{41}$

One notices straightaway the author's intention to make his case for Christian teaching from the scriptures; he names the Law, the Prophets, the Psalms, and the Gospel, scriptures that are named as they are named in the Qur'ān. Moreover, in emphasizing God, his Word, and his Spirit, the author recalls the Qur'ān's own mention of these three names in the often quoted phrase, "The Messiah, Jesus, Son of Mary, was nothing more than a messenger of God, his word that he imparted to Mary, and a spirit from him." (IV al-Nisā' 171) What is more, the author is willing to include explicit citations from the Qur'ān among the scripture passages he quotes in testimony to the credibility of the Christian doctrine. On the one hand, addressing the Arabic-speaking, Christian readers who were his primary audience, the author speaks of what "we find in the Law and the Prophets and the Psalms and the Gospel," in support of the Christian doctrines of the Trinity and the Incarnation. On the other hand, several times he rhetorically addresses Muslims; he speaks of what "you will find ... in the Qur'ān," and he goes on to cite a passage or a pastiche of quotations from several sürahs, in support of the doctrines, in behalf of the veracity of which he has been quoting or alluding to scriptural evidence from passages and narratives from the Old or New Testaments. ${ }^{42}$ For example, at one point in the argument, in search of testimonies to a certain plurality in the Godhead, the author turns to the scriptures for citations of passages in which God

${ }^{41}$ Dunlop Gibson, An Arabic Version, p. 3 (English), p. 75 (Arabic). Here the English translation has been adapted from Gibson's version.

${ }^{42}$ See, e.g., Dunlop Gibson, An Arabic Version, pp. 5-6 (English), pp. 77-78 (Arabic). See the passage quoted and discussed in Griffith, The Church in the Shadow, p. 55. 
speaks in the first person plural. Having quoted a number of such passages, he goes on to say:

\begin{abstract}
You will find it also in the Qur'ān that "We created man in misery (Q XC:4), and We have opened the gates of heaven with water pouring down (Q LIV:11), and have said, "And now you come unto Us alone, as We created you at first." (VI:94) It also says, "Believe in God, and in his Word; and also in the Holy Spirit." (cf. Q IV:171) The Holy Spirit is even the one who brings it down (i.e., the Qur'ān) as "a mercy and a guidance from thy Lord." (Q XVI:64, 102) But why should I prove it from this (i.e., the Qur'ān) and bring enlightenment, when we find in the Torah, the Prophets, the Psalms, and the Gospel, and you find it in the Qur'ān, that God and his Word and his Spirit are one God and one Lord? You have said that you believe in God and his Word and the Holy Spirit, so do not reproach us, O men, that we believe in God and his Word and his Spirit: we worship God in his Word and his Spirit, one God and one Lord and one Creator. God has made it clear in all of the scriptures that this is the way it is in right guidance and true religion. ${ }^{43}$
\end{abstract}

Evidently in this passage the Christian author is addressing himself directly, at least in part, to readers of the Qur'ān as well as to the devotees of the Christian Bible. He speaks of what "we find in the Torah, the Prophets, the Psalms, and the Gospel," and of what "you find ... in the Qur'ān." One also notices in this passage the prominence of the author's references to God, his Word, and his Spirit, and how they provide a continual evocation of sürah IV alNis $\bar{a}$ ' 171. Like almost every Arab Christian apologetic writer after him, the author of 'On the Triune Nature of God' takes this verse as Qur'annic testimony to the reality that the one God is in fact possessed of Word and Spirit and that they are He, the Son of God, and the Holy Spirit, three persons, one God, as the Christians say.

In a further passage, the author of 'On the Triune Nature of God' takes advantage of another verse in the Qur'ān to explain how it came about that by the action of the Holy Spirit, God's Word, the Son of God, became incarnate and was clothed, even veiled (ihtajaba), ${ }^{44}$ in Mary's human nature. "Thus," he says, "God was veiled (ihtajaba) in a man without sin." ${ }^{5}$ The "veiling' language here once again

${ }^{43}$ Translation adapted from Dunlop Gibson, An Arabic Version, pp. 5-6 (English), pp. 77-78 (Arabic).

${ }^{44}$ See Dunlop Gibson, An Arabic Version, p. 11 (English), p. 83 (Arabic).

${ }^{45}$ Dunlop Gibson, An Arabic Version, p. 13 (English), p. 85 (Arabic). 
evokes a particular passage in the Qur'ān: "God speaks with man only by way of revelation, or from behind a veil (hija $\bar{b}$, or he sends a messenger and he reveals by his permission what he wishes." (XLII al-Shürä 51) The author of our treatise likens Jesus' humanity to the veil, from behind which the Qur'ān says God might speak to man.

Subsequently a number of later 'Melkite' authors similarly allude to or quote from this passage from the Qur'ān in their explanations of the doctrine of the incarnation, extending from the ninth century into the thirteenth century. ${ }^{46}$ Curiously one does not find 'Jacobite' or so-called 'Nestorian' writers in Arabic much interested in this verse, suggesting that reference to it became something of a tradition in 'Melkite' apologetics. But all the early Arab Christian writers frequently quoted from and alluded to the Qur'ān, sometimes inexactly, as if from memory, and they regularly echoed its words and phrases in their ordinary discourse. ${ }^{47}$ Nevertheless, it seems to have been a 'Melkite' specialty to build whole apologetic arguments on selected passages from the Qur'ān, taking advantage of their readers' familiarity with the Islamic scripture and using its words and phrases for the evidentiary potential and probative value they had even among Arabic-speaking Christians.

A case in point may be seen in the pseudonymous, Arabic account of the 'Melkite' Theodore Abū Qurrah's encounter with a group of Muslim interlocutors in the majlis of the caliph, al-Ma'mūn. ${ }^{48}$ Some five times in the report, al-Ma'mūn is made to quote the phrase from the Qur'ān that exhorts its audience, "Do not debate with the People of the Book save in the fairest way." (XXIX al-'Ankabūt 46) ${ }^{49}$ Abu Qurrah in turn makes this phrase his own and he proceeds to quote the following phrase from the same Qur'ānic verse. In his words, it says, "We believe in what was sent down to us and to you. Your God and our God is one." Therefore, says Abū Qurrah to his Muslim interlocutor, "It is not for you to deny your own prophet's ennoble-

${ }^{46}$ See the passages cited in Swanson, "Beyond Prooftexting", pp. 298-302. See also Griffith, "Answers for the Shaykh", pp. 288 and 292.

${ }^{47}$ See Pietruschka, "Die Verwendung und Funktion von Koranzitaten". See also the brief study by Swanson, "A Frivolous God?".

${ }^{48}$ On this text see Bertaina, An Arabic Account of Theodore Abu Qurra; Nasry, The Caliph and the Bishop. See also Bertaina, Christian and Muslim Dialogues.

${ }^{49}$ On this verse and others that repeat the same phrase, see Dammen McAuliffe, "'Debate with them in the better way"”. 
ment of our religion." ${ }^{50}$ And he goes on from this point to say that when the Muslims recite the words of the first sürah in the Qur'ān, al-Fatihah, praying that God guide them to "the straight path, the path of those towards whom He has been gracious without being angry at them, they not going into error," (I al-Fätihah 6 \& 7) the fact is, says Abu Qurrah, that "those going astray are the very ones who are asking God to guide them to the 'the straight path'. Whereas, the ones 'toward whom $\mathrm{He}$ has been gracious' are actually the Christians, who believe in Him and in his Messiah." ${ }^{51}$ And so, Abū Qurrah concludes:

Your own scripture testifies in our behalf that we were of the People of the Book before you, believers in the Gospel and in the One who sent it down to us. You yourself acknowledge that our Lord, Jesus the Messiah, is in heaven (Q IV:158); to him belongs the Superiority over all the peoples, and all the prophets, and over everyone on the earth. Whoever follows him, to him belongs the superiority over all the religions. We are the Believers and you are the Muslims. (cf. Q II:6-7; XLIX:14) ${ }^{52}$

Immediately taking issue with Abū Qurrah's use of the Qur'ān's distinction between the 'Believers' and the 'Muslims', the Muslim interlocutor is presented as citing another passage for the Qur'ān: "Whoever follows a religion other than Islam, it will not be accepted from him; in the hereafter he will be among the losers." (III $\overline{A l}$ 'Imrān 85) Abū Qurrah responds with the following allegation:

Your own scripture abrogates this saying with its saying, 'God has made submit what is in the heavens and on the earth willy nilly'. (III $\overline{A l}$ 'Imrān 83) So there have entered into Islam all men, predators, wild animals, birds and other such things. And if it is as it says, then creatures altogether have become Muslims, whether they have willed it or refused it. And your status is only the status of one of them. ${ }^{53}$

According to the narrative, Abu Qurrah next cites two passages from the Qur'ān that tie the distinction between imān and isläm to

${ }^{50}$ Quoted from the author's translation of the passage as it appears in Paris Arabic MS 70, ff. 154v-155r; as published in Griffith, "The Qur'ān in Arab Christian Texts".

${ }^{51}$ Paris Arabic MS 70, f. 155v. Abu Qurrah's interpretation of this verse is contrary to the earliest Muslim interpretation, which designates the Christians as "those going astray". See, e.g., Muqātil b. Sulaymān, Tafsīr , vol. I, p. 26.

${ }_{52}$ Paris Arabic MS 70, f. 156r.

${ }^{53}$ Paris Arabic MS 70, ff. 156v-157r. 
the insinuation of a certain truculence on the part of the Arabs in religious matters (cf. XLIX al-Hujurāt 14 \& II al-Baqarah 6-7). And then he admonishes his interlocutor, "So do not be too proud O Muslim, to believe in the Word of God and his Spirit, the Creator of everything." ${ }^{54}$ According to the story, the Muslim interlocutor gets angry at this turn in the argument, while Abū Qurrah goes on to say:

Would your prophet, on God's authority, testify to something other than what He said? Far be it from him! He is the one who declared you devoid of faith. If you deny it, then you know best. As for me, I will put credence in what your scripture sets forth and what your prophet has uttered. ${ }^{55}$

These few quotations give a fair impression of how the Abū Qurrah character in the narrative is made to argue in the debate in the caliph's majlis. He can be quite sharp in his polemical indictments. For example, to al-Ma'mūn's statement that the enjoyment of the hüris of Paradise is intended for all the Muslims, Abū Qurrah responds,

If the matter is as you have recounted it, who will be the spouses of your Muslim women in the hereafter, when you will have abandoned them and will have chosen the hüris (Q XLIV:54, LV:56) over them? Then they will be in grief and sorrow, but you will be in joy and happiness with the hüris. If God provides wives for the men, but you do not provide husbands for the women, it is wrong. ${ }^{56}$

For the rest, the major part of the debate narrative is concerned with the proper thing to believe about the Word and the Spirit of God. In the course of it, the Abu Qurrah character manages to draw support for his Christian point of view from the construction he puts on those passages from the Qur'ān that concern the faith of the Christians. And he rebuts the negative view of the Christians that he says is current among the Muslims from the same source. For example, at one point Abū Qurrah says to his Muslim questioner:

You, in your mockery against us, and your anger toward us call us 'infidels' (käfirinn). Your scripture says, 'Whoever associates aught with God has erred a manifest error'. (Q IV:116) And again it says, 'You will surely find the Christians

${ }^{54}$ Paris Arabic MS 70, f. 158r.

55 Paris Arabic MS 70, ff. 158r-v.

${ }^{56}$ Paris Arabic MS 70, ff. 159r-v. 
doing well with what was sent down to them from the Lord'. ${ }^{57}$ So how can you say that we are 'Associators' (mushrikin), while your own prophet testifies in our behalf in terms of truth and judgment, and we are older than you are? ${ }^{58}$

In the debate, the Abū Qurrah character is portrayed as convicting his Muslim interlocutors of "belying the Psalms, the Gospel, and the Qur'ān. You deny God's scriptures because of the hardness of your heart." ${ }^{59}$ Whereas, he contends, "Your own scripture has removed all the Christians from polytheism and has acquitted them of disbelief ( $k u f r)$ by its mention of them in terms of favor and honor." ${ }^{60}$ This line of argument seems be at the heart of the debate text. Notice that in the just quoted passage, Abū Qurrah has included the Qur'ān along with the Psalms and the Gospel as books he calls "God's scriptures."

This same engagement with texts quoted from the Qur'ān is an integral feature of another popular 'Melkite' text that enjoyed a wide circulation among Arabic-speaking Christians from the ninth century onward even beyond the boundaries of the 'Melkite' community, the so-called, "Disputation of the Monk Ibrāhīm al-Ṭabarānī." ${ }_{61}$ It proved to be one of the most often copied texts in the distinctive apologetic-polemic genre, 'the monk in the emir's majlis', which was a favorite among Arab Christian composers of interreligious tracts in early Islamic times. ${ }^{62}$ The author delighted in presenting the monk as quoting passages from the Qur'ān for which he provided Christian-friendly interpretations to the consternation of his Muslim interrogators, and, one supposes, the amused satisfaction of the Christian readers of the text.

In the mid-to late eleventh century, the neglected 'Melkite' theologian, 'Afîf b. al-Makīn b. Mu'ammil composed a short treatise in fifteen sections that he called, Risālah mukhtașarah mushtamilah 'alā

${ }^{57}$ No such statement is to be found in the Qur'ān. The author seems to have put it together from elements in V al-Mā'idah $82 \& 68$.

${ }_{58}$ Paris Arabic MS 70, f. 162r.

59 Paris Arabic MS 70, f. 173r.

${ }_{60}$ Paris Arabic MS 70, f. 170r-v.

${ }^{61}$ See the edition, French translation, and abundant commentary in Bulus Marcuzzo, Le dialogue d'Abraham de Tibériade. See also Swanson, "The Disputation of the monk".

${ }^{62}$ See Griffith, "The Monk in the Emir's Majlis". 
madhāhib al-Nașārāa. ${ }^{63}$ On the face of it the treatise is a brief presentation of 'Melkite' Christology along with an account and a refutation of the Christological formulae of the community's theological adversaries, including the Maronites, who Ibn Mu'ammil, like other 'Melkite' writers, says espoused the Christological doctrines of Monotheletism and Monenergism. ${ }^{64} \mathrm{~A}$ close reading of the text however reveals that throughout the treatise, and not just in its last several sections, the author very much has the Muslim challenge in mind. ${ }^{65}$ His clear purpose, in a work that recalls earlier philosophical and theological language employed by Arab Christian writers, is the by now standard 'Melkite' program to set forth the Orthodox teaching about Christ, buttressed with echoes of Islamic discourse, and including allusions to a number of passages from the Qur'ān cited in support of the 'Melkite' creed. ${ }^{66}$

The highpoint of the 'Melkite' engagement with the Arabic Qur'ān for apologetic purposes came in the thirteenth century. The 'Melkite' monk of Antioch and bishop of Sidon, Paul of Antioch, who flourished at the turn of the twelfth and thirteenth centuries, ${ }^{67}$ was the author of some two dozen Arabic theological and philosophical texts, of which five have been edited in a modern critical edition and published in a French translation. ${ }^{68}$ Sometime in the early 1200's Paul wrote an apologetic treatise in the form of a 'Letter to a Muslim Friend' in Sidon, in which he skillfully deploys selected passages from the Qur'ān and Christian interpretations of them to build a de-

${ }^{63}$ See Graf, Geschichte der christlichen arabischen Literatur, pp. 78-79; Swanson, " Afïf ibn al-Makīn ibn Mu'ammal".

${ }^{64}$ See Cheikho and Batarekh, Trois traités, p. 87.

${ }^{65}$ For a detailed analysis of the text, see the forthcoming Ph.D. dissertation of Fr. Elie Estephan at the Catholic University of America, Washington, DC.

${ }^{66} \mathrm{By}$ this time the formulation of the 'Melkite' creed included the practice, also employed by Ibn Mu'ammil, of naming and refuting the views of the traditional, Greekspeaking adversaries of Chalcedonian Christology even in Arabic. See Griffith, "Theology and the Arab Christian".

${ }^{67}$ See Graf, Geschichte der christlichen arabischen Literatur, vol. II, pp. 72-78; Samir, Caspar et al., "Bibliographie du dialogue islamo-chrétien"; Nasrallah, Histoire de movement littéraire, vol. III, t. I, pp. 257-269; Gaudeul, Encounters \& Clashes, vol. I, pp. 187-190. See also Samir, "Notes sur la 'Lettre à un musulman"” and Thomas, "Paul of Antioch's Letter".

${ }^{68}$ Khoury, Paul d'Antioche. 
fense of Christianity against contemporary Muslim polemics. ${ }^{69}$ Paul's contention is that the Qur'ān enfranchises Christianity and proves that its doctrines are not such as to be equated with the unbelief (al-kufr) of the polytheists (al-mushrikün).

The letter opens with a frame story that features an account of the bishop's sojourn in what he calls "the homelands of the Romans [i.e., the Byzantines], Constantinople, the country of Amalfi, some Frankish provinces, and Rome," where he says he came into conversation with "the most important people ... their most eminent and learned men." "70 Paul says that his Muslim friend back in Sidon wanted to know what the learned men abroad thought of Muhammad, the Qur'ān, and Islam. In his letter he then proceeds to recount what these 'Byzantine' dignitaries allegedly had to say about the Arab prophet and his scripture and how they defended their basic Christian teachings by way of a Christian interpretation of selected passages from the Qur'ān, with Paul serving as their interlocutor and the one who puts forward the likely Muslim objections to their reasoning. In this letter Paul quotes from the Qur'ān, or alludes to Qur'ānic passages, some 64 times, citing or referring to 32 surrahs in order to bolster the argument that Muhammad was a prophet sent with the Arabic Qur'ān to the Arabs and not to other peoples; that Christians are believers in the one God and they are not polytheists, nor are they called by God to accept Islam or the Qur'ān. Moreover, Paul offers interpretations of Qur'ānic verses to support the reasonableness of Christian doctrines, including the doctrines of the Trinity and the Incarnation, the Orthodox doctrine of the union of divinity and humanity in Christ, and even the integrity of the Christian scriptures and the superiority of Christianity as a religion over Judaism and Islam.

It was not long before Paul's 'Letter to a Muslim Friend' came to the attention of Muslim scholars. Just a few years after its composition and circulation in his own 'Melkite' community, the famed Muslim jurist of Cairo, Shihāb al-Dīn Aḥmad b. Idrīs al-Qarāfī (12281285), came across the text and included, without mentioning his name, a refutation of Paul's arguments and his interpretations of passages from the Qur'ān point by point in this Muslim author's

${ }^{69}$ See the Arabic text and French translation in Khoury, Paul d'Antioche, III, pp. 5983 (Arabic), pp. 169-187 (French).

${ }^{70}$ See Khoury, Paul d'Antioche, pp. 69-70 (Arabic), pp. 169-170 (French). 
anti-Christian polemical work, al-Ajwibah al-fäkhirah. ${ }^{71}$ Subsequent$1 y$, in the early years of the fourteenth century, some now anonymous, Arabic-speaking, 'Melkite' Christians in Cyprus edited and expanded Paul's letter and sent copies to two prominent Muslim scholars of the day, to Ibn Taymiyyah (1263-1328) in 1316 and to Ibn Abī Țālib alDimashqi (d.1327) in 1321, both of whom wrote rejoinders to the Cypriots' considerably revised edition of Paul's original letter. ${ }^{72}$

\section{The Arab Orthodox Church}

Looking back from the vantage point of the fourteenth century, when in Mamlūk times Muslim polemicists were sharpening their refutations of Christians, sparked in no small part by the challenge of Paul of Antioch's 'Letter to a Muslim Friend' and its subsequent use by Christian apologists, one can see that an integral component of the 'Melkite' reaction to the Arab conquests of the seventh century, after accrediting the mayhem of the invasions as punishment for sin and heresy, ${ }^{73}$ was their choice to respond to the challenge in both cultural and theological terms. From the very beginning, as we have seen, the proto-'Melkites' perceived the basic theological challenge to lie in what the conquering Arabs believed about Christ and they quickly came to characterize this Arab belief in Christian terms as a heresy, and more specifically as Arianism. In this respect, one can see that they considered their struggle with Islam in some sense to be a continuation of the Christological debates in which they were already embroiled. In the treatises and tracts of the Arabic-speaking, 'Melkite' writers from the eighth to the thirteenth centuries, and especially in their creedal summaries, ${ }^{74}$ one can see the continued presentation of their Chalcedonian faith within the frame work of their polemics not only against Muslims but also against the rival Christologies of the 'Jacobites' and the 'Nestorians' and other Christian adversaries. And in their specific responses to Muslims they one and all argued that the Qur'ān itself in what it has to say about Jesus,

${ }^{71}$ Al-Qarāfì, al-Ajwibah al-fäkhirah, pp. 21-73.

72 See Thomas, "Paul of Antioch's Letter"; Ebied and Thomas, Muslim-Christian Polemic during the Crusades; Michel, A Muslim Theologian's Response.

${ }^{73}$ See Griffith, The Church in the Shadow, pp. 32-35.

${ }^{74}$ As noted above, see Griffith, "Theology and the Arab Christian". 
the Messiah, Mary's son, actually affirms the veracity of the working of God's Word and Spirit in him. Indeed, argument from the Arabic Qur'ān in behalf of Christians and their doctrines became something of a hallmark of 'Melkite' theological discourse in Arabic. And this phenomenon in turn calls attention to the adoption of the Arabic language on the part of the 'Melkites' as itself an important component of their reaction to the Arab conquests.

Culturally speaking, the 'Melkites', whose liturgical and theological language had been and in many ways continued to be Greek, were faced after the conquest with a situation unlike that of the 'Jacobites', the Copts, the Armenians, and the members of the Church of the East. The latter communities retained their traditional languages as both their ecclesiastical and everyday idiom well into the Islamic era. At the same time, for the 'Melkites', Greek became evermore a specialized tongue in the Oriental Patriarchates, cultivated among ecclesiastics and scholars, many of whom seem after the ninth century even to have required textbooks to learn it. ${ }^{75}$ By the end of the first Abbasid century, 'Melkites' were speaking and writing Arabic not only in their daily affairs but in church related matters as well; among them translations of theological, canonical, and other ecclesiastical texts from Greek into Arabic continued to be produced well into the thirteenth century. In this process the Arab Orthodox Church came into its own, with consequences reaching even into the present day. Arabicization, and along with it a good measure of acculturation into the life and thought of the Muslim polity, proved to be the church's long-term reaction to the Arab conquest in the seventh century.

\section{Bibliography}

Bertaina, David, An Arabic Account of Theodore Abū Qurra in Debate at the Court of Caliph al-Ma'mūn: A Study in Early Christian and Muslim Literary Dialogue, Ph. D. Dissertation, Washington, DC, The Catholic University of America, 2007.

Bertaina, David, Christian and Muslim Dialogues: The Religious Uses of a Literary Form in the Early Islamic Middle East, Piscataway, NJ, Gorgias Press, 2011, Gorgias Eastern Christian Studies, 29.

75 See Griffith, "What Has Constantinople to Do?”. 
Bottini, Laura, "The Apology of al-Kindī," in Thomas, David et al. (ed.), Christian-Muslim Relations: A Bibliographical History, Leiden, Brill, 2009-, vol. I, pp. 585-594.

Bulus Marcuzzo, Giacinto, Le dialogue d'Abraham de Tibériade avec 'Abd alRahmān al-Hāshimì à Jérusalem vers 820, Rome, Pontificio Istituto Orientale, 1986, Textes et Études sur l'Orient Chrétien, 3.

Busse, Heribert, "Die "Umar-Moschee im östlichen Atrium der Grabeskirche," Zeitschrift des deutschen Palästina-Vereins, 109 (1993), pp. 73-82.

Busse, Heribert, "Monotheismus und islamische Christologie in der Bauinschrift der Felsendoms in Jerusalem," Theologische Quartalschrift, 161 (1981), pp. 168-178.

Busse, Heribert, "Zur Geschichte und Deutung der frühislamischen Harambauten in Jerusalem," Zeitschrift des deutschen Palästina-Vereins, 107 (1991), pp. 144-154.

Cheikho, L. and Batarekh, E. (ed.), Trois traités anciens de polémique et de théologie chrétiennes, Beirut, Dār al-Mashriq,1923.

Cragg, Kenneth, The Arab Christian: A History in the Middle East, Louisville, KY, Westminster-John Knox, 1991.

Dammen McAuliffe, Jane, "'Debate with them in the better way', The Construction of a Qur'ānic Commonplace", in Neuwirth, Angelica et al. (ed.), Myths, Historical Archetypes and Symbolic Figures in Arabic Literature: Towards a New Hermeneutic Approach, Beirut, In Kommission bei Franz Steiner Verlag Stuttgart, 1999, pp. 163-188.

Dodge, Bayard (ed. and transl.), The Fihrist of al-Nadim: A Tenth-Century Survey of Muslim Culture, New York, Columbia University Press, 1970.

Dunlop Gibson, Margaret (ed.), An Arabic Version of the Acts of the Apostles and the Seven Catholic Epistles from an Eighth or Ninth Century MS in the Convent of St Catharine on Mount Sinai, with a Treatise on The Triune Nature of God, with Translation, from the Same Codex, Cambridge, Cambridge University Press, 1899, Studia Sinaitica, VII.

Ebied, Rifaat and Thomas, David (ed. and transl.), Muslim-Christian Polemic during the Crusades: The Letter from the People of Cyprus and Ibn Abi Tālib al-Dimashqī's Response, Leiden, Brill, 2005, The History of Christian-Muslim Relations, vol. II.

Gallo, Maria (transl.), Palestinese anonimo; Omelia arabo-cristiana dell'VIII secolo, Roma, Città Nuova Editrice, 1994.

Gaudeul, J.-M., Encounters \& Clashes: Islam and Christianity in History, Rome, Pontificio Istituto di Studi Arabi e d'Islamistica, 2000, Collection 'Studi arabo-islamici del PISAI', 15.

Grabar, Oleg, The Dome of the Rock, Cambridge, Mass., Belknap Press of Harvard University Press, 2006.

Grabar, Oleg, The Shape of the Holy: Early Islamic Jerusalem, Princeton, NJ, Princeton University Press, 1996. 
Graf, Georg, Geschichte der christlichen arabischen Literatur, Vatican City, Biblioteca Apostolica Vaticana, 1944-1953.

Griffith, Sidney H., "Anastasios of Sinai, the Hodegos, and the Muslims," Greek Orthodox Theological Review, 32 (1987), pp. 341-358.

Griffith, Sidney H., "Answers for the Shaykh: A 'Melkite' Arabic Text from Sinai and the Doctrines of the Trinity and the Incarnation in 'Arab Orthodox' Apologetics," in Grypeou, E., Swanson, M. and Thomas, D. (ed.), The Encounter of Eastern Christianity with Early Islam, Leiden, Brill, 2006, pp. 277-309, The History of Christian-Muslim Relations, vol. 5.

Griffith, Sidney H., "From Aramaic to Arabic: The Languages of the Monasteries of Palestine in the Byzantine and Early Islamic Periods", Dumbarton Oaks Papers, 51 (1997), pp. 11-31.

Griffith, Sidney H., "Giovanni di Damasco e la chiesa in Siria all'Epoca degli Omayyadi", in Chialà, S. and Cremaschi, L. (a cura di), Giovanni di Damasco. Un padre al sorgere dell'Islam. Atti del XIII Convegno ecumenico internazionale di spiritualità ortodossa, sezione bizantina, Bose, 11-13 settembre 2005, Magnano, Qiqajon, 2006, pp. 21-52.

Griffith, Sidney H., "John of Damascus and the Church in Syria in the Umayyad Period", Hugoye: Journal of Syriac Studies, 11, 2 (2011), pp. 207-237.

Griffith, Sidney H., “'Melkites', 'Jacobites', and the Christological Controversies in Arabic in Third/Ninth=Century Syria," in Thomas, David (ed.), Syrian Christians under Islam: The First Thousand Years, Leiden, Brill, 2001, pp. 9-55.

Griffith, Sidney H., The Church in the Shadow of the Mosque: Christians and Muslims in the World of Islam, Princeton, NJ, Princeton University Press, 2008.

Griffith, Sidney H., "The Church of Jerusalem and the 'Melkites': The Making of an 'Arab Orthodox' Christian Identity in the World of Islam (750-1050 CE)," in Limor, Ora and Stroumsa, Guy G. (ed.), Christians and Christianity in the Holy Land: From the Origins to the Latin Kingdom, Turnhout, Belgium, Brepols, 2006, pp. 175-204.

Griffith, Sidney H., "The Life of Theodore of Edessa: History, Hagiography, and Religious Apologetics in Mar Saba Monastery in Early Abbasid Times," in Patrich, Joseph (ed.), The Sabaite Heritage in the Orthodox Church from the Fifth Century to the Present, Leuben, Peeters, 2001, pp. 147-169, Orientalia Lovaniensia Analecta, 98.

Griffith, Sidney H., "The Monk in the Emir's Majlis: Reflections on a Popular Genre of Christian Literary Apologetics in Arabic in the Early Islamic Period," in Lazarus-Yafeh, Hava et al. (ed.), The Majlis: Interreligious Encounters in Medieval Islam, Wiesbaden, Harrassowitz, 1999, pp. 13-65, Studies in Arabic Language and Literature.

Griffith, Sidney H., "The Monks of Palestine and the Growth of Christian Literature in Arabic", The Muslim World, 78 (1988), pp. 1-28. 
Griffith, Sidney H., “The Qur'ān in Arab Christian Texts: The Development of an Apologetical Argument: Abū Qurrah in the Mağlis of al-Ma'mūn", $P a-$ role de l'Orient, 24 (1999), pp. 203-233.

Griffith, Sidney H., "Theology and the Arab Christian: The Case of the 'Melkite' Creed", in Thomas, David (ed.), A Faithful Presence: Essays for Kenneth Cragg, London, Melisende, 2003, pp. 184-200.

Griffith, Sidney H., "What Has Constantinople to Do with Jerusalem? Palestine in the Ninth Century; Byzantine Orthodoxy in the World of Islam," in Brubaker, Leslie (ed.), Byzantium in the Ninth Century: Dead or Alive?, Aldershot, UK and Brookfield, 1998, pp. 181-194, Papers from the Thirtieth Spring Symposium of Byzantine Studies, Birmingham, March 1996.

Guillaume, A. (transl.), The Life of Muhammad: A Translation of Ibn Ishaq's Sirat Rasul Allah, Karachi, Oxford University Press, 1967.

Haddad, Robert M., "Conversion of Eastern Orthodox Christians to the Unia in the Seventeenth and Eighteenth Centuries," in Gervers, Michael and Bikhazi, Ramzi Jibran (ed.), Conversion and Continuity: Indigenous Christian Communities in Islamic Lands; Eighth to Eighteenth Centuries, Toronto, Pontifical Institute of Medieval Studies, 1990, pp. 449-459, Papers in Medieval Studies, 9.

Haddad, Robert M., Syrian Christians in Muslim Society: An Interpretation, Princeton, NJ, Princeton University Press, 1970.

Hoyland, Robert G., Arabia and the Arabs: From the Bronze Age to the Coming of Islam, London and New York, Routledge, 2001.

Hoyland, Robert G., Seeing Islam As Others Saw It: A Survey and Evaluation of Christian, Jewish and Zoroastrian Writings on Early Islam, Princeton, NJ, Darwin Press, 1997, Studies in Late Antiquity and Early Islam, 13.

Kessler, Christel, "Abd al-Malik's Inscription in the Dome of the Rock: A Reconsideration", Journal of the Royal Asiatic Society, (1970), pp. 2-14.

Khoury, Paul (ed. and transl.), Paul d'Antioche: évèque de Sidon (XII es.), Beyrouth, Imprimerie Catholique, 1964.

Lampe, G. W. H., A Patristic Greek Lexicon, Oxford, Clarendon Press, 1961.

Le Coz, Raymond (ed.), Jean Damascène, Écrits sur l'Islam, Paris, Les Éditions du Cerf, 1992, Sources Chrétiennes, 383.

Louth, Andrew, St John Damascene: Tradition and Originality in Byzantine Theology, Oxford, Oxford University Press, 2002.

Michel, Thomas, A Muslim Theologian's Response to Christianity: Ibn Taymiyya's al-Jawab al-Sahih, Delmar, NY, Caravan Books, 1984.

Munitiz, Joseph A., (ed. and transl.), Anastasios of Sinai: Questions and Answers, Turnhout, Brepols, 2011, Corpus Christianorum in Translation, 7.

Muqātil b. Sulaymān, Tafsīr, Beirut, Dār al-Kutub al-'Ilmiyya, 1424/2002.

Nasrallah, Joseph, Histoire de movement littéraire dans l'église melchite du Ve au XXe siècle, Louvain, Peeters, 1979-1989. 
Nasry, Wafik, The Caliph and the Bishop: A $9^{\text {th }}$ Century Muslim-Christian Debate: al-Ma'mūn and Abū Qurrah, Beyrouth, CEDRAC-Université Saint Joseph, 2008, Textes et Études sur l'Orient Chrétien, 5.

Noble, Samuel and Treiger, Alexander (ed.), The Orthodox Church in the Arab World (700-1700): An Anthology of Sources, DeKalb, IL, Northern Illinois University Press, 2012.

Pietruschka, Ute, "Die Verwendung und Funktion von Koranzitaten in christlichen Apologien der frühen Abbasidenzeit (Mitte 8. Jahrhundert - Anfang 10. Jahrhundert)," in Beltz, Walter and Tubach, Jürgen (ed.), Religiöser Text und soziale Struktur, Halle, Martin-Luther Universität Halle-Wittenberg, 2001, pp. 271-288, Hallesche Beiträge zur Orientwissenschaft, 31.

Platti, Emilio, "Des arabes chrétiens et le Coran: Pérennité d'une polémique," in De Smet, G., Callataÿ, G. de and Van Reeth, J. M. F. (ed.), Al-Kitāb: La sacralité du texte dans le monde de l'Islam, Bruxelles, Louvanin-La-Neuve, Leuven, The Belgian Society of Oriental Studies, 2004, pp. 333-345, Acta Orientalia Belgica, Subsidia III.

Al-Qarāfī, Shihāb al-Dīn Aḥmad b. Idrīs, al-Ajwibah al-fākhirah 'an al-as'ilah al-fäjirah fì radd 'alā l-millah l-kāfirah, Majd̄̄ Muhammad al-Shihāwī (ed.), Beirut, 'Ālam al-Kutub, 1426/2005.

Roggema, Barbara, “A Christian Reading of the Qur'ān: The Legend of SergiusBahīrā and its Use of Qur'ān and Sīra," in Thomas, David (ed.), Syrian Christians under Islam: The First Thousand Years, Leiden, Brill, 2001, pp. 57-73.

Roggema, Barbara, The Legend of Sergius Bahīrā: Eastern Christian Apologetics and Apocalyptic in Response to Islam, Leiden, Brill, 2009, The History of Christian-Muslim Relations, vol. 9.

Samir, Samir Khalil, "La rivoluzione cultural introdotta a Baġdād dai Cristiani", in Righi, Davide (ed.), La Letteratura Arabo-Cristiana e le Scienze nel Periodo Abbaside (750-1250 d.C.), Torino, Silvio Zamorani, 2008, pp. 3557, Patrimonio Culturale Arabo-Cristiano, 11.

Samir, Samir Khalil, "Notes sur la 'Lettre à un musulman de Sidon' de Paul d'Antioche", Orientalia Lovaniensia Periodica, 24 (1993), pp. 179-195.

Samir, Samir Khalil, "The Christian Communities, Active Members of Arab Society throughout History", in Pacini, Andrea (ed.), Christian Communities in the Arab Middle East: The Challenge of the Future, Oxford, Clarendon Press, 1998, pp. 67-91.

Samir, Samir Khalil, "The Earliest Arab Apology for Christianity (c.750)," in Samir, Samir Khalil and Nielsen, Jøgen S. (ed.), Christian Arabic Apologetics during the Abbasid Period (750-1258), Leiden, Brill, 1994, pp. 57-114, Studies in the History of Religions, vol. 63.

Samir, Samir Khalil, Caspar, R. et al., "Bibliographie du dialogue islamochrétien: Auteurs chrétiens de langue arabe; Būlus ar-Rāhib al-Anțākī (fin XII'-début XIII siècle)", Islamochristiana, 2 (1976), pp. 232-236. 
Swanson, Mark N., "A Frivolous God? (A-fa-ḥasibtum annama khalaqnākum 'abathan)", in Thomas, David and Amos, Clave (ed.), A Faithful Presence: Essays for Kenneth Cragg, London, Melisende, 2003, pp. 166-183.

Swanson, Mark N., "Afîf ibn al-Makīn ibn Mu'ammal”, in Thomas, David et al. (ed.), Christian-Muslim Relations: A Bibliographical History, Leiden, Brill, 2009-, vol. II, pp. 714-718.

Swanson, Mark N., "The Disputation of the monk Ibrāhīm al-Ṭabarān̄̄," in Thomas, David et al. (ed.), Christian-Muslim Relations: A Bibliographical History, Leiden, Brill, 2009-, vol. I, pp. 876-881.

Swanson, Mark N., "Beyond Prooftexting: approaches to the Qur'ān in some early Arabic Christian apologies", The Muslim World, 88 (1998), pp. 297319.

Thomas, David, "Paul of Antioch's Letter to a Muslim Friend and The Letter from Cyprus," in Thomas, David (ed.), Syrian Christians under Islam: The First Thousand Years, Leiden, Brill, 2001, pp. 203-221.

Thomas, David et al. (ed.), Christian-Muslim Relations: A Bibliographical History, Leiden, Brill, 2009-.

Tien, A. (ed.), Risālah 'Abd Allāh b. Ismā'ūl al-Hāshimì ilā 'Abd al-Masīh b. Ishạa al-Kind̄̄ yad'ūhu bihā ilā l-islām wa risālah 'Abd al-Masīh ilā l-Hāshimī yad'ūhu ilā n-nașrāniyyah, London, Society for Promoting Christian Knowledge, 1885.

Uthemann, Karl-Heinz, Anastasii Sinaitae Viae Dux, Turnhout, Brepols and Leuven University Press, 1981.

Wilken, Robert L., The Land Called Holy: Palestine in Christian History and Thought, New Haven, CT, Yale University Press, 1992.

Recibido: 30/01/2012

Aceptado: 04/06/2012 